\title{
SOIL SURFACE CRUST: ITS SIGNIFICANCE, TYPES AND MECHANICS OF FORMATION. A REVIEW
}

\author{
Yousif H. Al-Nasser \\ Qahtan D. Al-Kafagi \\ Soil Sciences and Water Resources Dept./ College of Agriculture and Forestry/ \\ University of Mosul/ Iraq \\ Email:alnaseryousif10@uomosul.edu.iq
}

\begin{abstract}
Most of the agricultural soils around the world suffer from increased soil degradation and erosion and reduce moisture conservation, which is the decisive factor in agricultural crop production, and among these problems is the phenomenon of Surface Soil Crusting (SSC), which is spread in a wide range of climates, especially in dry and semi-arid soils. In this review, the focus was done on the significance of SSC, its formation mechanisms, stages of emergence, types of crusts, methods used to estimate crust hardness and its resistance to penetration. It was noted that SSCs are formed when raindrop falls on newly plowed soils or soils without vegetation, followed by periods of drought, thus destroying soil aggregates and splashing there fine particles, these particles enter the inter-pores, Leading to formation of hard thin layers at the soil surface with thickness ranges from several millimeters to several centimeters or these particles moved by surface runoff water to deposit in the bottom of valleys, forming a sedimentary crust of five to seven centimeters thick. The SSC are generally divided into three main parts, namely, structural crusts, sedimentional crusts, in addition to the Biological soil crusts, which is formed over the previous two types and consists of fungi, algae, lichens and bacteria. Crust hardness can be measured or estimated by two main methods, which are Modulus of Rupture, and crust Penetration Resistance.
\end{abstract}

Keywords: surface crust, Soil structure, Biological crusts, Resistance to penetration

Received: 30 /9 / 2020 Accepted: 2/12/2020

\section{INTRODUCTION}

The continuous increase of world's population needs food resources sufficient to meet the growing needs for food, at the time the world suffers from climate changes and the deterioration of agricultural lands (Šimanský et al., 2014), agricultural land degradation occurs escalating pace and affect areas inhabited by more than one third of the world's population (Valentin and Bresson, 1992), the consequences of this have negatively affected soil productivity due to salinization or desertification the soils (Sela et al.,2012).

Recent studies have tended in many countries around the world to search for new means and methods to improve soil structure, organic carbon and moisture conservation by making use of the remains of previous crop (El-Naggar et al., 2018) or adding agricultural residues and animal waste (Fan and $\mathrm{Wu}, 2020$ ) and adding some low-cost natural rocks as phosphogypsum or lime (Borselli et al., 1996 and Al-Nasser and Al-Khalid, 2020) to improve soil health and its sustainability (Choudhury et al., 2014, Opoku-Kwanowaa et al., 2020). 
Most agricultural soils, especially in arid and semi-arid regions, suffer from some physical and chemical problems, such as salinization, alkalinity, structure deterioration, low aggregations and low organic matter content (Sela et al., 2014 and Acir and Gunal, 2020), and to reduce these problems or reduce their negative effects on soil and agricultural production (Pires et al., 2017). Many researchers in the field of soil management and conservation (Agassi et al., 1985, Pagliai et al., 2000b, Sela et al., 2012 and Pires et al., 2017) recommended that more experiments and research be conducted in order to improve the properties of degraded soils that suffer from some problems and constraints that affect their productivity to obtain the best economic return. From exploiting these lands while preserving their properties from degradation (Wilhelm et al., 2010 and Fan and $\mathrm{Wu}, 2020$ ). One of these problems is the phenomenon of SSC, which is widespread in a wide range of soils, especially in soils of arid and semi-arid regions with a clay or silty texture that contain extended clay minerals from smectite group 2:1 (Scott et al., 2015).

SSCs are occur in the soil surface layer resulting from natural conditions such as the effect of raindrops strikes followed by drying process (Fox et al., 2004), leading to formation of a thin, solid layer on the soil surface, its thickness usually ranges from less than $1 \mathrm{~mm}$ to $5 \mathrm{~cm}$ (Šimanský et al., 2014), and when it dries up, these appearances become stiffer than the lower soil materials (Fajardo et al., 2016). This dense layer not only reduces the size and number of pores, but also changes pores arrangement (Pagliai et al., 2004, Neave and Rayburg 2007). Soil crusting occurs in a wide range of soils and causes danger not only in very dry areas but also in all climatic systems (Armenise, et al., 2108). In temperate regions, soil crusts develop rapidly after rainfalls on plowed soil with loamy texture, the same problem arises in soils of tropical regions (Nciizah and Wakindiki 2014 and Mahesh et al., 2018).

\section{SURFACE SOIL CRUST}

SSC is generally thin layer soil ranging in thickness from $1 \mathrm{~mm}$ by (Bresson et al., 2004) to more than $10 \mathrm{~mm}$ (Bresson and Valentin, 1993), more densely packed than the underlying horizon, ranged from 1.75 to $1.95 \mathrm{Mg} \mathrm{cm}^{-3}$ for soils with silty sand loamy, sand or sandy loam textures, crusts of loess-derived soils showed lower values, ranging from 1.65 to $1.75 \mathrm{Mg} \mathrm{cm}^{-3}$, In the top few millimeters of the crust, porosity is low and it gradually increases with depth (Mahesh et al., 2018). Strong crusts with high bulk densities may impede aeration under moist conditions by preventing effective diffusion of oxygen into the soil. Lack of aeration becomes a problem for germination of seeds which led to decrease in seedling emergence (Wakindiki and Ben-Hur, 2002).

Soil capability for crusting depends on different soil physical properties (soil texture, soil building, clay content and moisture content) (Opoku-Kwanowaa et al., 2020), soil chemical properties (organic matter and exchangeable sodium ratio in soil) (Wakindiki and Ben-Hur, 2002 and Rabot et al., 2018), and external factors (degree of pressure generated by the effect of raindrops or sprinkler irrigation, temperature, and the speed of surface drying) (Taha, 2016). 
The crust occurs when rain falls on lands with less vegetation cover or newly plowed lands, and after the soil dries up, the surface layer of it hardens, forming a hard crust with little porosity, which impedes the emergence of seedlings and adversely affects agricultural production (Graef and Stahr, 2000), reduces infiltration rate, moisture storage, and increased surface runoff (Carmi and Berliner, 2008) and increased soil erosion (Fox et al., 2004, Sela et al., 2014, and Al-Naser, 2018), the presence of a layer of high bulk density above the soil surface reduces the aeration of the soil and negatively affects the growth of young plants inside the soil body (Fox et al., 2004 and Graef and Stahr, 2000) in addition to the rupture of roots and young plants sometimes when the crusts dry up and crack (Giannetta et al., 2018).

Chen et al., (2013) reported that SSCs have both internal and external morphological differences depending on soil texture, type of clay minerals, bonding materials, rain intensity and drying speed (Scott et al., 2015). Soils newly plowed or devoid of vegetation are affected to different degrees by raindrop energy according to the content of organic matter, clay, iron and sodium oxides present in the exchange complex (Bresson et al., 2004) that affect the aggregate stability. When soils are exposed to rain storms, the falling raindrops can generate a number of different responses, as shown in the table (1):

Table (1): The response of soil surface to raindrops

\begin{tabular}{|c|c|c|}
\hline INPUT & Rain splash erosion & Removal of macro aggregates \\
\cline { 3 - 3 } RAIN & & Removal of discrete particles \\
\cline { 2 - 3 } DROP & In situ surface processes & Breakdown of structural units \\
\cline { 3 - 3 } ENERGY & & Surface of particle sorting \\
\cline { 3 - 3 } & & Surface compaction \\
\cline { 2 - 3 } & Input rain drop energy & In wash of material in to soil \\
\hline
\end{tabular}

\section{Stages of Crust Formation}

Scott et al., (2015) indicated that crust formation, the occurrence of runoff and soil erosion passes through several stages, and that the response of the soil surface to the energy of the falling raindrops is divided into two main parts, the first part is the splashing of particles by the fallen raindrops (Romkens et al., 1990 and Pulido Moncada et al., 2014), and the fine particles enter the intermediate pores to create a crust with low porosity (Norton, 1987). The second part is when the soil is wetting (Bresson and Valentin, 1993 and Pagliai et al., 2004), and the soil aggregates dissolved and their parts expanded by swelling (Bronnikova, 2011), sometimes air is trapped in large pores, resulting in air vesicles that may open to the outside (air explosion) (Neave and Rayburg, 2007), this condition occurs when rain falls on dry soils, which leads to clogging of the soil surface, increased runoff, and soil loss (Fajardo et al., 2016). It increases the process of clogging the pores and increasing the surface run-off, thus increasing soil erosion. The following table illustrates this: 
Table (2): The effect of raindrops on crust formation, runoff, and soil loss

\begin{tabular}{|l|c|c|c|c|c|}
\hline \multirow{3}{*}{ Rainfall } & Splash & Crusting & \multirow{4}{*}{} & & \\
\cline { 2 - 3 } & \multirow{2}{*}{ Wetting } & Swelling & Slaking & \multirow{2}{*}{ Runoff } & Soil loss \\
& & & & \\
& & & & \\
\end{tabular}

\section{Mechanism of Soil Crust Formation}

SSCs differ in their mechanism and composition from one region to another according to the intensity and amount of precipitation, soil texture, soil aggregation and structural stability (Choudhury et al., 2014 and Chen et al., 2020). Water and dissolved solutes determine the spatial arrangement of soil particles, therefore, a saturated or near saturated soil is essential for crust formation. As soil dries out, soil water tension increases, bringing the particles closer together (Fajardo et al., 2016). Thus the combined effects of increased soil water tension, reduced pore size and increased number of contact points enhance bond formation. The nature of exchangeable cations also affects the particle distribution and packing (Neave and Rayburg, 2007).

McIntyer (1958) stated that the SSC is formed as a result of effect of two processes: the first is mechanical by the action of direct raindrops falling on the soil. The second is a process of physiochemical dispersal of soil aggregates (Romkens et al., 1990), and in this process the transferred particles of clay and silt contribute to the clogging of pores, especially large pores, and upon drought this layer becomes solid with a high apparent density and low permeability to water and air as well as reducing the emergence of small seedlings (Nciizah and Wakindiki, 2014). The following mechanisms play an important role in formation of structural crusts as reported by Fox et al., (2004) and Fan and Wu (2020):

1- The topsoil aggregations are mechanically destroyed by the direct effect of rain drops, which work to break down soil aggregates and separate soil particles from each other. This process occur in most type of soils, especially in clay and silty clay soils, when the aggregations stability is very low, due to lack of organic matter, iron oxides, lime and other binders (Šimanský et al., 2014 and Scott et al., 2015).

2- Washing and transferring of fine soil particles and depositing them in the underlying soil pores (Chen et al., 2013).

3- Compression of the soil surface by the direct effect of falling raindrops, thus forming a thin layer with a high bulk density and low porosity that reduces the entry of water into the soil pores (Taha, 2016). So, the fine soil particles move with the tip of the water and are deposited in the inter-pores forming the washed-in layer and when it dries up and hardens, the surface crust is formed (Wakindiki and BenHur, 2002 and William et al., 2010) consisting of two parts: the first layer is approximately $0.1 \mathrm{~mm}$ thick resulting From the pressure resulting from the impact of direct raindrops (Scott et al., 2015), the second part is the fine soil particles that are dispersed by the raindrops and enter the inter-pores with the infiltration water, causing clogging under the first layer with a thickness of $2 \mathrm{~mm}$ and McIntyre (1958) called it the washed-in layer. 
3- The cohesion of the topsoil saturated with water after drying and redirecting the soil particles (Fox et al., 2004).

4- The topsoil layer consolidates upon drying and re-orientation of surface soil particles after what was saturated with water, which causes the hardness of the soil crusts (Fox et al., 2004).

\section{Types of Soil Crusts}

Arshed and Mermut (1988) mentioned that there are three main categories of soil crust:

A- Disruptional crust: It is formed immediately after the destruction of soil aggregates under the influence of raindrops in silty soils.

B-Sedimentional Crust: It is formed in soils with surface runoff at the bottom of slopes or within the micro relief of soil surface.

C- Laminar Crust: It is formed in soils with a high content of exchangeable magnesium and sodium.

A surface sealing layer is the dissolution of soil weak surface layer formed as a result of irrigation or during rainstorms on clay or silty clay soils (Rabot et al., 2018). This processes is attributed to collapse or breakdown of fragile soil aggregates, leading to clogging the pores and formation of a thin layer about 0.1 mm thick (McIntyre, 1985). In wet months the silty soil disperses, especially in the depressed parts of the field, resulting in the formation of a clogging layer up to 7 $\mathrm{cm}$ thick, and during the following dry conditions the surface clogs transformed into SSC (Aubert et al., 2011).

SSC can generally be divided into three main types in terms of its mechanics: 1- Structural crust: This type of crust formed by the direct effect of raindrops on the soil surface (William et al., 2018), Usually these crusts are very thin 1-3 mm thick and have more porosity than the depositional crusts (Aubert et al., 2011). These crusts consist of two layers: the first is called Seal layer, which is a thin layer with a thickness of approximately $1 \mathrm{~mm}$ (Arshed and Murmut, 1988), and it formed as a result of the dissolution of soil aggregates and their compaction by action of falling raindrops. The second is called washing layer, and it is formed when the soil fine particles are transported with infiltration water and deposited directly in the interfacial pores of the sub-surface layer, causing its blockage (Bowker et al., 2016). The sub-types of this type of crust (structural crust) are: a) Slaking crusts, b) Infiltrating crusts, c) Coalescing crusts, d) Sieving crusts.

2- Sedimentional Crust: These crusts are formed when soil aggregates are dissolved after rain falls and fine soil particles (coarse clay and fine silt) are transferred by surface runoff and deposited in the Interfacial pores or deposited at the end of the slopes, and they also form in the micro-relief topography of the land (Belnap et al., 2004 and Carmi and Berliner, 2008). The thickness of these crusts reaches several centimeters (Chen et al., 2013). Chahinian et al., (2006) mentioned that the thickness of these crusts ranges between $0.6-20 \mathrm{~mm}$ with very low porosity, while Bronnikova (2011) and Laker and Nortj (2019) mentioned that the thickness of these crusts is more than $50 \mathrm{~mm}$ and consists of several microebed layers (thin laminate layer) and each layer represents one rainstorm. The Sedimentional crust is divided into two secondary types, namely; erosion crusts and depositional crusts (Bresson et al., 2004). 
3- Biological Crust: This type of crust also called Cryptogamic or Cryptobiotic Soil Crust. It is surface crust formed from algae, fungi, lichens, algae and bacteria over Structural crust (Chin et al., 2013 and Chen et al., 2020) or above erosional or sedimentation crusts, and because it is composed of a microbiological layer known as Microbiotic Soil Crust (Wakindiki and Ben-Hur, 2002 and Fan and Wu, 2020). Since these crusts are formed due to the proliferation of microbes on the above crusts, they are sometimes not considered as soil crust (Belnap et al., 2004).

Biological Crust is a thin layer of living materials that forms in the upper millimeters of soil, where soil particles are collected by a community of microorganisms. It is primarily found in open spaces in extremely dry and cold regions of all continents, where extreme conditions prevent the growth of many plants (Bowker et al., 2016). In many areas, biological soil crusts are important for soil stabilization, moisture retention and soil fertility, and have a major impact on global ecosystems, as they are important sources of carbon in areas with little vegetation cover (Belnap and Büdel 2016). Cyanobacteria and lichens in crusts convert atmospheric nitrogen into organic compounds that leach into the surrounding soil, as well as crusts with rough surfaces that slow down water runoff and increase water infiltration into the soil (Ferrenberg et al., 2017).

\section{Soil Properties Related to Crust Formation}

Soil susceptibility to crusts depends not only on external factors such as the effect of falling raindrops, but also on the following internal soil factors (Laker and Nortj, 2019):

1) Soil Texture: the particle size distribution of soil, especially clay and silt, affects the formation of soil crusting. The high clay content encourages the development of soil aggregates and reduces the rate of crust formation. The medium-textured soils (less than $20 \%$ of the clay) very susceptible to crusting, and that the coarse particles on the surface of the soil protect smaller soil aggregates from the influence of direct raindrops, in the same way that mulching works, thus increasing infiltration and reducing erosion (Carmi and Berliner, 2008; Chen et al., 2013 and Al-Naser, 2018).

2) Clay Minerals: Soils containing Smectite, Illite, and Muscovite are more prone to crusting, while Kaolinites minerals are less prone to crusting (Nciizah and Wakindiki, 2014 and Opoku-Kwanowaa et al., 2020).

3) Organic Matter content: It is considered one of the most important stabilizing factors for soil aggregations (Duwig et al., 2020), thus protecting the soil from dispersion under the influence of rain drops (Sela et al., 2012).

4) Sesquioxides Content: Iron and aluminum oxides encourage the formation of soil aggregates (Graef and Stahr, 2000 and Aubert et al., 2011).

5) Exchangeable Cations: Some cations (exchangeable sodium and sometimes magnesium) play an important role in crust formation due to their ability to disperse colloids and flocculate those (Choudhury et al., 2014).

6) Moisture Content: when precipitation covers dry soil, the water moves to the pressure of the air in front of it due to swelling, so the aggregates are destroyed and air bubbles exit, and as a result, the aggregates collapse (Bronnikova, 2011). 


\section{Methods Used to Determine the Soil Crust Strength}

There are three main Parameters that can be used to determine the strength of the surface soil crust:

1- Modulus of Rupture: This parameter gives indication of the hardness of the crust; it is estimated by placing a piece of crust of a certain dimensions and thickness under the influence of a special machine, and when the mold is broken. The force required to break the mold can be estimated according to Ashby (2011): $\mathrm{M}=(3 * \mathrm{~F} * \mathrm{~L}) /\left(2 * \mathrm{~b} * \mathrm{~d}^{2}\right)$

M: Modulus of Rupture (dyne $/ \mathrm{cm}^{2}$ ), F: force to break mold (dyne), L: distance between anchor points $(\mathrm{cm}), \mathrm{b}$ : mold width $(\mathrm{cm}), \mathrm{d}$ : mold thickness or height $\left(\mathrm{cm}^{2}\right)$.

2- Penetration resistance: The hardness of crust can be estimated by pocket penetrating device, which is a devise, with a flat head of a certain diameter that is pressed perpendicular to crust layer, and when the crust breaks under the influence of this pressure, the reading is determined directly from the device by the (dyne $\mathrm{cm}^{-2}$ or $\mathrm{kg} \mathrm{cm}^{-2}$ ) (Hadas and Frenkle 1982).

3- Seedling emergence examination: This parameter can be determined by measuring the ability of the seedlings to push the crust layer upwards by using different sizes of penetration to represent the emergence of seedlings of different diameters.

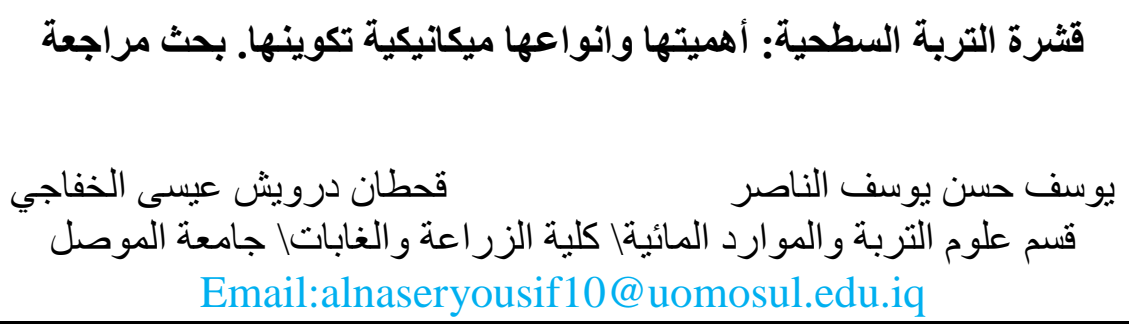


السابقين وتتالف من الفطريات والطحالب والاشنات والبكتريا. يمكن قياس أو تقدير صلابة القشرة بطريقتين رئيسيتين، وهما فحص معامل الكسر وقياس مقاومة القشرة للاختراق بالاضافة الى طريقة بزوغ البادرات.

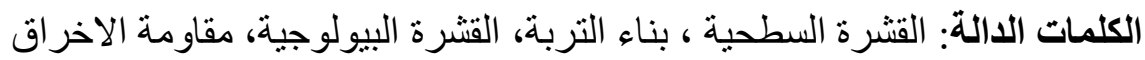

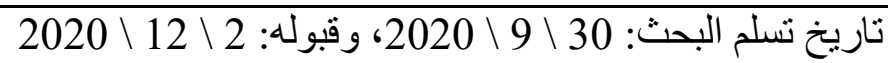

\section{REFERENCES}

Acir, N. and H. Gunal (2020). Soil quality of a cropland and adjacent natural grassland in an arid region. Carpathian Journal of Earth and Environmental Sciences.15(2):275-288.DOI: 10.26471/cjees/2020/015/128.

Agassi, M., J. Morin and I. Shainberg (1985). Effect of raindrop impact energy and water salinity on infiltration rates of sodic soils. Soil Science Society of America Journal49: 186 - 190.

Al-Naser, Y.H. (2018). Effect of phosphogypsum on formation and development of soil surface crust and wheat crop growth. Tikrit Journal for Agricultural Sciences. 18(3), 90-95.

Al-Nasser, Y.H. and A. Khalid (2020). The behavior and pattern of soil cracks and its managements in Vertisols. Mesopotamia journal of Agriculture, 48(2): 68-76.

Armenise, E., R.W. Simmons, S. Ahn, A. Garbout, S.H. Doerr, S.J. Mooney, C.J. Sturrock and K. Ritz (2018). Soil seal development under simulated rainfall: Structural, physical and hydrological dynamics. Journal of Hydrology, 556:211-219. DOI: 10.1016/j.jhydrol.2017.10.073.

Arshad, M.A. and A.R. Mermut (1988). Micro morphological and physicochemical characteristics of soil crust types in northwestem Alberta, Canada. Soil Science Society of America Journal, 52: 724-7 29.

Ashby, M.F. (2011). Materials Selection in Mechanical Design. 4th Edition. Kidlington, Oxford, UK. Pp :616-620.

Aubert, M., N. Baghdadi, M. Zribi, A. Douaoui, C. Loumagne, F. Baup, M. El Hajj and S. Garrigues (2011). Analysis of Terra SAR-X data sensitivity to bare soil moisture, roughness, composition and soil crust. Remote Sensing Environment 115(8): 1801-1810.

Belnap J and B. Büdel (2016). Biological Soil Crusts as Soil Stabilizers. Biological soil crusts: an organizing principle in drylands. New York, NY: Springer International Publishing. pp 305-320.

Belnap, J, S.L. Phillips and M.E. Miller (2004). Response of desert biological soil crusts to alteration in precipitation frequency. Oecologia, 141(2), 306316. DOI:10.1007/s00442-003-1438-6. PMID 14689292

Borselli, L., R. Biancalani, C. Giordani and S. Camicelli (1996). Effect of gypsum on seedling emergence in a kaolinitic crusting soil. Soil Technology 9:7I-81.

Bowker, M.A, J. Belnap and B. Büdel (2016). Controls on Distribution Patterns of Biological Soil Crusts at Micro- to Global Scales. Biological Soil Crusts: an Organizing Principle in Drylands.173-179

Bresson, L., C. Moran and S. Assouline (2004). Use of bulk density profiles from X-radiography to examine structural crust models. Soil Science Society of America Journal, 68: 1169-1176. 
Bresson, L.M. and C. Valentin (1993). Soil surface crust formation: contribution of micromorphology. Developments in Soil Science, 22:737-762. DOI:10.1016/S0166-2481(08)70460-4.

Bronnikova, M.A. (2011). Interpretation of micromorphological features of soils and regoliths. Eurasian Soil Science, 44: 824-828.

Carmi, G. and P. Berliner (2008). The effect of soil crust on the generation of runoff on small plots in an arid environment, Catena, 74(1): 37-42, DOI:10.1016/j.catena.2008.02.002.

Chahinian, N., M. Voltz, R. Moussa and G. Trotoux (2006). Assessing the impact of the hydraulic properties of a crusted soil on overland flow modeling at the field scale, Hydrological Proceses, 20(8): 1701- 1722.

Chen N., K. Yu, R. Jia, J. Teng and C. Zhao (2020). Biocrust as one of multiple stable states in global dry lands. Soil Advances, 6:39. DOI: 10.1126/sciadv.aay3763

Chen, L., S. Sela, T. Svoray and S. Assouline (2013). The roles of soil-surface sealing, microtopography and vegetation patches in rainfall-runoff processes in semiarid areas. Water Resources Research, 49: 1-15.

Choudhury, S.G., S. Srivastava, R. Singh, S.K. Chaudhari, D.K. Sharma, S.K. Singh and D. Sarkar (2014). Tillage and residue management effects on soil aggregation, organic carbon dynamics and yield attribute in rice-wheat cropping system under reclaimed sodic soil. Soil Tillage Research, 136: 7683.

Duwig, C., K. Müller, F.Morari and P.J. Delmas (2020). Foreword to 'Linking Soil Structure and Soil Functions', Soil Research, 57, 6. https://doi.org/10.1071/SRv57n6_FO

El-Naggar, Y.I., T.A. Eid and S.A. Ali (2018). Effects of Mulching Soil on Water Consumption, Yield, Fruit Quality and Water Use Efficiency of "Canino" apricot (Prunus armeniaca L.) Cultivar. Journal of Plant production, 9(12): $1003-1018$.

Fajardo, M., A.B McBratney, D.J. Field and B. Minasny (2016). Soil slaking assessment using image recognition. Soil and Tillage Research. 163:119129.

Fan, W. and J. Wu (2020). Short-term effects of returning granulated straw on soil microbial community and organic carbon fractions in dryland farming Journal of Microbiology. 58(8):657-667. DOI 10.1007/s12275-020-9266-5.

Ferrenberg, S., C.L Tucker and S.C. Reed (2017). Biological soil crusts: diminutive communities of potential global importance. Frontiers in Ecological and the E nvironment, 15 (3) 160-167. DOI:10.1002/fee.1469.

Fox, D.M., R.B. Bryan and A.G. Price (2004). The role of soil surface crusting in desertification and strategies to reduce crusting. Environmental Monitoring and Assessment, 99(3): 149-159.

Fox, D.M., R.B. Bryan and C.A. Fox (2004). Changes in pore characteristics with depth for structural crusts. Geoderma, 120 (1-2): 109-120.

Giannetta, B., C. Plaza, C. Vischetti, M.F. Cotrufo and C. Zaccone (2018). Distribution and thermal stability of physically and chemically protected 
organic matter fractions in soils across different ecosystems. Biology and Fertility of Soils 54(5):671-681. DOI:10.1007/s00374-018-1290-9.

Graef, F. and K. Stahr (2000). Incidence of soil surface crust types in semiarid Niger. Soil \& Tillage Research, 55:213-218. DOI.org/10.1016/S01671987(00)00117-3.

Hadas, A. and H. Frenkel (1982). Infiltration as affected by long-term use of sodicsaline water for irrigation, Soil Science Society of America Journal, 46(3), 524-530.

Laker, C.M and G.P. Nortjé (2019). Review of existing knowledge on soil crusting in South Africa. Advances in Agronomy. 155: 189-242.

Mahesh, C.H., R. Malavath, T. Anjaiah and D. Balaguruvaiah (2018). Genesis, classification and evaluation of some sugarcane-growing black soils in semi arid tropical region of telangana. Journal of Pharmacognosy and Phytochemistry. 7(3): 81-92.

McIntyre, D. (1958). Permeability measurements of soil crusts formed by raindrop impact. Soil Science, 85(4): $185-189$.

Nciizah, A. and I. Wakindiki (2014). Rainfall pattern effects on crusting, infiltration and erodibility in some South African soils with various texture and mineralogy. Water SA, 40(1):57. DOI: 10.4314/wsa.v40i1.7

Neave, M. and S. Rayburg (2007). A field investigation into the effects of progressive rainfall-induced soil seal and crust development on runoff and erosion rates: The impact of surface cover, Geomorphology, 87(4): 378-390, DOI:10.1016/j.geomorph.2006.10.007.

Norton, L. (1987). Micromorphological study of surface seals developed under simulated rainfall. Geoderma 40(1-2): $127-140$.

Opoku-Kwanowaa, Y, J. Wu, X. Chen, A. Sharaf and S.G. Attipoe (2020). Soil physicochemical properties variation in black soil after the long-term application of different organic amendments. Asian Journal of Advances in Agricultural Research, 12(2): 24-34. DOI: 10.9734/ajaar/2020/v12i230079.

Pagliai M., Vignozzi N., S. Pellegrini, P. Ceccon, R.Giovanardi and C.Coiutti, (2000b).Impact of difîerent cropping systems on soil porosity and structure. Italian Journal of Agronomy, 4, 43-51.

Pagliai, M. N. Vignozzi and S. Pellegrini (2004). Soil structure and the effect of management practices, Soil \& Tillage Research, 79: 131-143.

Pires, L.F., J.A. Borges, J.A. Rosa, M. Cooper, R.J. Heck, S. Passoni and W.L. Roque (2017). Soil structure changes induced by tillage systems. Soil and Tillage Research. 165, 66-79.

Pulido Moncada, M., D. Gabriels, D. Lobo, K. De Beuf, R.Figueroa and W.M.Cornelis (2014). comparison of methods to assess susceptibility to soil sealing. Geoderma Journal, 226-227, 397-404.

Rabot, E., M.Wiesmeier, S.Schlüter and H.J. Vogel (2018). Soil structure as an indicator of soil functions: A review. Geoderma, 314, 122-137. https://doi.org/10.1016/j.geoderma.

Romkens, M.J., S.N. Prasad and J.Y. Parlange (1990). Surface seal development in relation to rainstorm intensity. Soil erosion-Experiments and models, Catena supplement, 17: 1-11. 
Scott, F., S.C. Reed and B. Jayne (2015). Climate change and physical disturbance cause similar community shifts in biological soil crusts. Proceed. Natural Academy Science. 112 (39): 12116- 12121. DIO:10.1073/pnas.1509150112.

Sela, S., T. Svoray and S. Assouline (2014). Soil surface sealing effect on soil moisture at a semiarid hillslope: Implications for remote sensing estimation. Remote Sensing. 6: 7469-7490, DOI:10.3390/rs6087469.

Sela, S., T. Svoray and S. Assouline (2012). Soil water content variability at the hillslope scale: Impact of surface sealing. Water Resources Research. 48,114.

Šimanský, V., N Polláková and S. Halmo (2014). Soil crust in agricultural land. Scientific Journal for Phytotecgnhc and Zootechnica, 17(4): 109-114. DOI: 10.15414/afz.2014.17.04.109-114.

Taha, R.H. (2016). Soil Surface Crust Formation as Affected by Adding Organic Nanomaterials. Doctor's Thesis, Faculty of Agriculture, Alexandria University, Egypt, pp.45-60.

Valentin, C. and L.M. Bresson (1992). Morphology, genesis and classification of surface crusts in loamy and sandy soils. Geoderma, 55: 225-245.

Wakindiki, I. and M. Ben-Hur (2002). Soil mineralogy and texture effects on infiltration, and crust micromorphology erosion. Soil Science Society of America Journal, 66(3):897. DOI:10.2136/sssaj2002.8970.

West, L. T.; S. C. Chiang and L. D. Norton (1992). The Morphology of Surface Crusts, in: Sumner M.E. and Stewart B.A. (Eds.), Soil Crusting: Chemical and Physical Processes, Lewis Publishers, Boca Raton, FL, USA. pp. 73-92.

Wilhelm, W., J.R. Hess, D.L. Karlen, J.M. Johnson, J. Muth, J.M. Baker, H. Gollany, J. Novak, D.E. Stott and G.E. Varve (2010). REVIEW: Balancing limiting factors \& economic drivers for sustainable Midwestern US agricultural residue feedstock supplies. Industrial Biotechnology 6(5):271287. DOI: 10.1089/ind.2010.6.271. 